
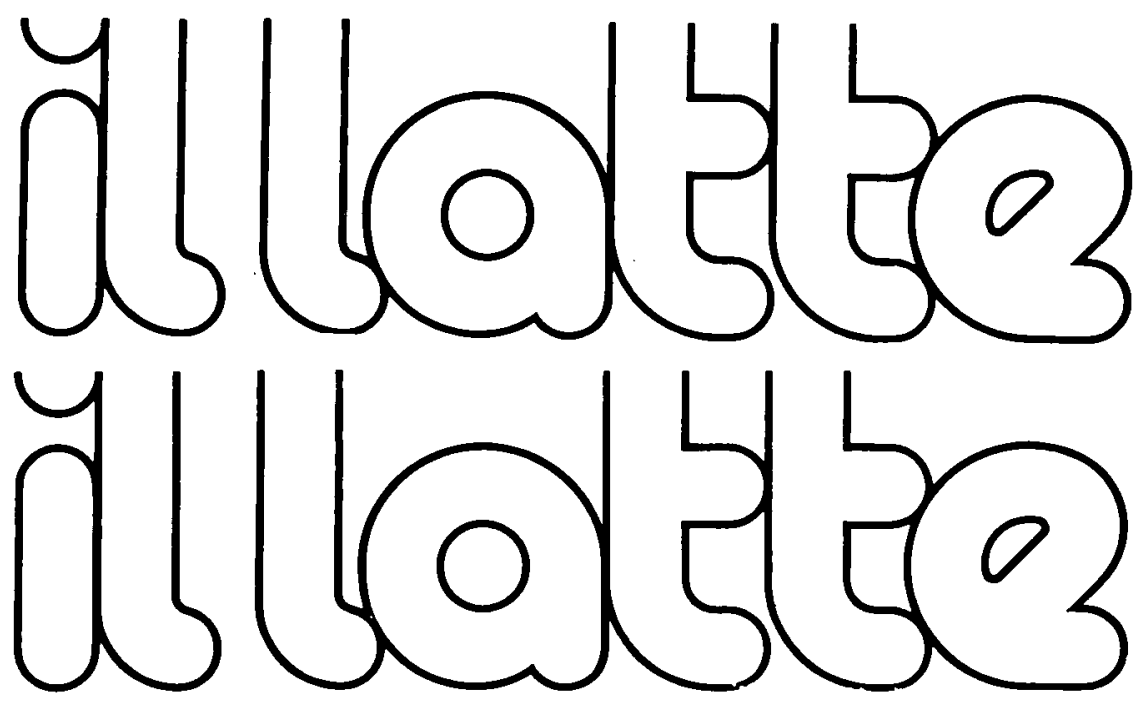

Is a.monthly magazine offering practical, experimental and scientific information on dairy techniques.

It is a high level publication read both in industrial and university milieus.

IL LATTE was founded over 50 years ago and has now a new typographical format to give

a more modern and comprehensive review of each and every feature of the dairy world.
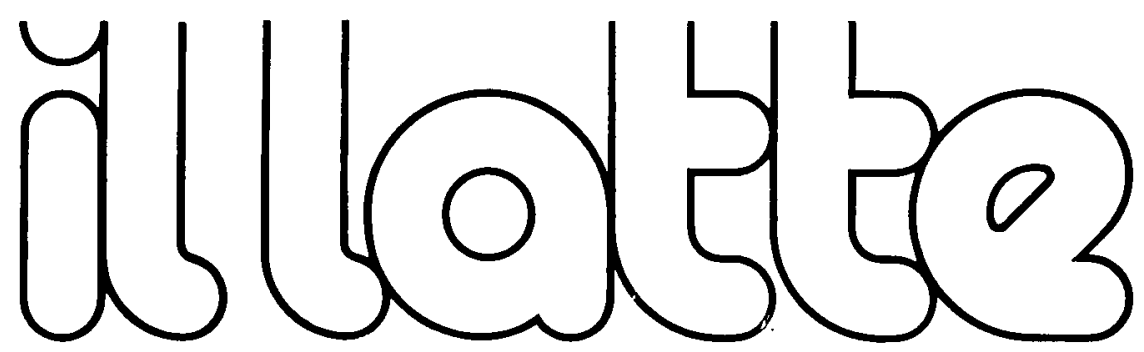

If you wish to receive a sample copy, please send your request to

\title{
techiche nuove
}

Vla Moscova 46ra - 20121 Mllano (Italy) - Tel. 0265900355 (8 linee) - Telex 334647 TECHS I 


\section{DIRECTIONS TO CONTRIBUTORS}

\section{GENERAL}

Two copies of manuscripts should be sent to Dr M. E. Sharpe (The Journal of Dairy Research), National Institute for Research in Dairying, Shinfield, Reading, RG2 9AT, England. Submission of a paper will be held to imply that it reports unpublished original work, that it is not under consideration for publication elsewhere, and that if accepted for the Journal it will not be published elsewhere in any language, without the consent of the Editors.

\section{FORM OF PAPERS}

The author should follow these directions carefully, and consult a current issue of the Journal for guidance on details of typographical and other conventions.

Every paper should be headed with its title, the names and initials of the authors (each author supplying one given name) and the name and address of the laboratory where the work was done.

Papers should be in English, using the spelling of the Shorter Oxford English Dictionary. They should be typed with double spacing, on one side only of the sheets, and with ample margins for editorial annotations.

Papers should in general be divided into the following parts in the order indicated: (a) Summary, brief and self-contained; (b) Introductory paragraphs, briefly explaining the object of the work but without giving an extensive account of the literature; (c) Experimental or Methods; $(d)$ Results; ( $e$ ) Discussion and Conclusions; ( $f$ ) Acknowledgements without a heading; $(g)$ References. With some types of material headings other than $(c),(d)$ and $(e)$ may be preferable.

The use of footnotes should be avoided if possible. Underlining should be used only to indicate italics. Proper nouns, including trade names, should be given a capital initial letter. Wherever possible numerals should be used unless this leads to ambiguity. The typescript should carry the name and address of the person to whom the proofs are to be sent, and give a shortened version of the paper's title, not exceeding 45 letters and spaces, suitable for a running title in the Journal.

\section{TABLES}

Tables should be numbered and should carry headings describing their content. They should be comprehensible without reference to the text. They should be typed on separate sheets and their approximate positions in the text indicated. To minimize the cost of printing, the number and size of tables should be kept to an absolute minimum.

\section{ILLUSTRATIONS}

Line drawings and photographs, which must be originals, should be numbered as Figures in Arabic numerals. Drawings should be in Indian ink, on Bristol board or cartridge paper. However, a technique which may be more convenient to authors is to use a doublesized piece of tracing paper, or translucent graph paper faintly lined in blue or grey, folded down the centre with the drawing on one half and the other half acting as a flyleaf.

Attached to every figure and plate there should be a translucent flyleaf cover on the outside of which should be written legibly: (a) title of paper and name of author; (b) figure or plate number; (c) the figures and lettering, which are intended to appear on the finished block, in the correct positions relative to the drawing underneath. Each paper should have a separate typed sheet listing figure and plate numbers with their legends, and the approximate positions of illustrations should be indicated in the text.

The photographs and diagrams should be about twice the size of the finished block and not larger overall than the sheets on which the paper itself is typed. For a figure measuring $250 \mathrm{~mm} \times 150 \mathrm{~mm}$ all lines, axes and curves should be $0.4 \mathrm{~mm}$ thick, thus Graph symbols in order of preference are $\bigcirc \bullet, \Delta \boldsymbol{\Delta}$, $\square \square, x+$, and for a $250 \mathrm{~mm} \times 150 \mathrm{~mm}$ graph the circles should be $3 \mathrm{~mm}$ in diam. The triangles should be equilateral of $3 \mathrm{~mm}$ side, and the squares also of $3 \mathrm{~mm}$ side. The crosses should have lines $3 \mathrm{~mm}$ long at right angles. Scale marks on the axes should be on the inner side of each axis and should be $3 \mathrm{~mm}$ long.

\section{SHORT COMMUNICATIONS}

Short communications or notes of not more than $\mathbf{2 5 0 0}$ words or the equivalent space in print and without a summary will also be published.

\section{REFERENCES}

In the text, references should be quoted by whichever of the following ways is appropriate: Arnold \& Barnard (1900); Arnold \& Barnard (1900a); Arnold \& Barnard $(1900 a, b)$; (Arnold \& Barnard, 1900). Give both names for 2 authors. For 3 or more authors give the first name $e t$ al. on all occasions, adding $a, b$, etc., to the date if there is any ambiguity.

References should be listed alphabetically at the end of the paper. Titles of journals should be given in full, authors' initials should be included, and each reference should be punctuated in the typescript thus: Arnold, T. B., Barnard, R. N. \& Compound, P. J. 1900. Title of paper. Journal of Dairy Research 18, 158-165 and references to books should include names of authors, year of publication, title, names of editors, town of publication and name of publisher in that order, thus: Arnold, T. B. 1900 Dairying. London: Brown and Chester. References should include titles of papers to which they refer.

It is the duty of the author to check all references.

\section{UNITS, SYMBOLS AND ABBREVIATIONS}

SI units must be used, as explained in British Standards Institution publication PD 5686:1972. The use of SI units. Until SI units are widely understood, it is permissible to give the equivalent value in other units in parenthesis. Symbols and abbreviations used are those of British Standard 1991: Part 1: 1967. Letter Symbols, Signs and Abbreviations.

\section{DESCRIPTIONS OF SOLUTIONS}

Normality and molarity should be indicated thus: $\mathrm{N}-\mathrm{HCl}, 0 \cdot 1 \mathrm{M}-\mathrm{NaH}_{2} \mathrm{PO}_{4}$. The term ' $\%$ ' means $\mathrm{g} / 100 \mathrm{~g}$ solution. For $\mathrm{ml} / 100 \mathrm{ml}$ solution the term " $\%(\mathrm{v} / \mathrm{v})$ " should be used and for $\mathrm{g} / 100 \mathrm{ml}$ solution the correct abbreviation is ' $\%(w / v)$ '.

\section{OFFPRINTS}

Order forms giving quotations for offprints are sent to authors with their proofs. 


\section{CONTENTS}

obituary: Professor J. W. G. Porter, M.A., Ph.D. (Cantab.), F.I. Biol.

ORIGINAL ARTICLES

Some observations on the behaviour of dairy cattle using cow-activated out-of-parlour concentrate dispensers

W. LITTLE and R. D. HARRISON

Distribution, location, and ultrastructure of plasma cells in the

uninfected, lactating bovine mammary gland

S. C. NICKERSON, J. W. PANKEY and N. T. BODDIE

Effect of prazosin on the function of the teat sphincter in lactating cows G. VANDEPUTTE-VAN MESSOM, J. BERNABÉ, C. BURVENICH and G. PEETERS

$N$-acetyl- $\beta$-D-glucosaminidase (NAGase) levels in bulk herd milk B. J. KITCHEN, G. MIDDLETON, W. SENG KWEE and R. J. ANDREWS

Glucose levels in normal and mastitic milk

R. J. MARSCHKE and B. J. KITCHEN

Lipid composition of milks from cows with experimentally induced mastitis

E. C. NEEDS and M. ANDERSON

Studies on micellar calcium phosphate: composition and apparent solubility product in milk over a wide $\mathrm{pH}$ range

L. C. CHAPLIN

Purification and characterization of porcine $\kappa$-casein

J. CERNING-BEROARD and C. ZEVACO

Chemical characterization of milk concentrated by ultrafiltration M. L. GREEN, K. J. SCOTT, M. ANDERSON, M.C. A. GRIFFIN and F. A. GLOVER

Isolation and composition of milk fat globule membrane material.

I. From pasteurized milks and creams

A. V. MCPHERSON, M. C. DASH and B. J. KITCHEN

Isolation and composition of milk fat globule membrane material.

II. From homogenized and ultra heat treated milks

A. V. MCPHERSON, M. C. DASH and B. J. KITCHEN

Changes in viscosity of processed creams during storage at $5{ }^{\circ} \mathrm{C}$ K. R. LANGLEY

A procedure for the complete clarification of milk of various species and its suitability for use with colorimetric measurements

$$
\text { A. J. OWEN and A. T. ANDREWS }
$$

Factors affecting the volume of milk delivered by a standard loop in the plate loop method for bacterial count

J. S. KING and L. A. MABBITT

An automatic method for measuring the heat coagulation time of milk powder solutions

H. FOISSY and W. KNEIFEL

Assessment of the suitability for Cheddar cheesemaking of purified and commercial chicken pepsin preparations

M. L. GREEN, M. J. VALLER and J. KAY

REVIEW ARTICLE

Reviews of the progress of Dairy Science: The bacteriological, chemical, biochemical and physical changes that occur in milk at temperatures of $100-150^{\circ} \mathrm{C}$

H. BURTON

(C) Proprietors of The Journal of Dairy Research 1984

Printed in Great Britain at the University Press, Cambridge 